\title{
PERAN PERCEIVED USEFULNESS DAN PERCEIVED RISK SEBAGAI VARIABEL PEMEDIASI PADA PENGARUH PERCEIVED EASE OF USE DAN EWOM NEGATIF TERHADAP NIAT PEMBELIAN PARA PENGGUNA APLIKASI LAYANAN KESEHATAN HALODOC
}

\author{
Ursila Imro’atu Wakhida \\ Universitas Negeri Surabaya \\ ursilawakhida16080574001@mhs.unesa.ac.id \\ Sanaji \\ Universitas Negeri Surabaya \\ sanaji@unesa.ac.id
}

Abstract

\begin{abstract}
Competition in the business world today is increasingly fierce in the era of globalization. Information technology can shift the way of practice and change the way of thinking in the business world. The rapid development of technology makes the economy also increasingly developing. One of them is the innovation in the field of online health services. This study aims to examine the effect of perceived ease of use and negative EWOM on purchase intentions with perceived usefulness and perceived risk as mediating variables in Halodoc health service application users in East Java. This study uses 200 samples with non-probability sampling techniques and the method used is a judgmental sampling. The data collection method is done by distributing questionnaires online. The data analysis technique used in this study is the path analysis technique. Based on the results of research conducted, it was found that perceived ease of use has a positive effect on purchase intentions with perceived usefulness as a mediating variable, and negative EWOM has no effect on purchase intentions because perceived risk does not mediate between these relationships in Halodoc health service applications. Based on these results, it is recommended that Halodoc health service application makers pay attention to the ease of use of the application and the benefits that can be felt by consumers and prospective consumers when using the application so that a positive EWOM is formed to reduce the risks that exist in the application and have an impact on purchase intentions towards health services in the application.
\end{abstract}

Keywords: negative e-WOM; perceived ease of use; perceived risk; perceived usefulness; purchase intention.

\section{PENDAHULUAN}

Teknologi informasi di era globalisasi dapat menggeser cara praktik dan mengubah cara berpikir dalam dunia bisnis, misalnya jika sebelumnya dalam praktik bisnis optimal sering dianggap sebagai prinsip utama, hal ini bisa ditunjukkan dengan perubahan prinsip optimal yaitu dengan kehadiran teknologi informasi yang membuat prinsip ini dipertanyakan lagi, sehingga bukan optimalisasi yang memegang peran penting, namun inovasilah yang memegang kunci (Mildawati, 2016). Dengan adanya inovasi baru yang berkembang dengan cepat membuat prinsip optimalisasi bukan menjadi tolak ukur keberhasilan suatu usaha (Mildawati, 2016). Perkembangan teknologi yang semakin cepat membuat perekonomian juga semakin berkembang. Salah satunya adanya inovasi di bidang jasa layanan kesehatan online. Kesehatan merupakan salah satu di antara sektor startup yang potensial untuk digali di Indonesia. Dalam kurun waktu singkat, sejumlah startup di bidang kesehatan mulai sering bermunculan untuk menawarkan kemudahan, baik dalam mencari info seputar kesehatan hingga pemberian pelayanan (Maulana, 2017).

Munculnya start up kesehatan telah menciptakan beberapa konsep baru di bidang teknologi layanan kesehatan online (Maulana, 2017). Tingkat penerimaan sistem informasi tersebut dapat berpedoman pada teori Technology Acceptance Model (TAM). Model ini pertama kali diperkenalkan oleh Fred Davis pada tahun 1986. Ada tiga faktor yang memengaruhi penggunaan sebuah sistem sesuai yang diusulkan oleh Fred Davis, yaitu perceived usefulness, perceived ease of use, dan intention to use. Menurut Davis (1989), perilaku menggunakan teknologi informasi diawali oleh adanya persepsi mengenai manfaat (usefulness) dan persepsi mengenai kemudahan menggunakan teknologi informasi (ease of use). Salah satu modifikasi TAM yaitu Trust and Risk in Technology Acceptance Model 
(TRITAM) yang menggunakan variabel kepercayaan dan risiko bersama variabel TAM (Lui \& Jamieson, 2003). Penelitian ini menggunakan teori TRITAM dengan menambahkan variabel perceived risk karena menurut Kucukusta (2015:188), bahwa TAM harus diintegrasikan ke dalam model yang lebih luas yang akan mencakup variabel seperti proses perubahan manusia dan sosial, dan adopsi model inovasi.

Perceived ease of use merupakan suatu tingkat atau keadaan di mana seseorang yakin bahwa dengan menggunakan sistem atau aplikasi tertentu tidak diperlukan usaha apapun (free of effort) atau dengan kata lain teknologi tersebut dapat dengan mudah dipahami oleh pengguna (Davis, 1989). Terdapat pengaruh tidak langsung yang signifikan antara perceived ease of use terhadap intention melalui perceived of usefulness (Eriska, 2018). Menurut Damayanti (2019), persepsi kegunaan tidak memiliki pengaruh positif dan signifikan terhadap niat pembelian. Sedangkan menurut Eriska (2018), terdapat pengaruh yang signifikan antara perceived of usefulness terhadap intention. Oleh karena itu, penelitian ini menggunakan variabel perceived usefulness sebagai variabel mediasi pada hubungan antara perceived ease of use terhadap niat pembelian karena ditemukan adanya inkonsistensi peranan variabel tersebut. Perceived usefulness adalah sejauh mana seseorang percaya bahwa menggunakan suatu teknologi akan meningkatkan kinerjanya (Davis, 1989). Persepsi manfaat dalam e-commerce merupakan keyakinan konsumen tentang sejauh mana ia akan menjadi lebih baik dari transaksi online dengan aplikasi tertentu (Kim, et.al, 2008).

Dalam penelitian ini, EWOM ditambahkan dalam teori TRITAM, karena EWOM dapat memengaruhi salah satu variabel dalam teori TRITAM. Informasi yang diberikan melalui EWOM kemudian digunakan sebagai pertimbangan bagi konsumen sebelum melakukan pembelian jasa. Tingginya aktivitas EWOM akan menurunkan persepsi risiko konsumen sehingga mendorong minat pembelian secara online (Indiani et.al, 2015). Oleh sebab itu, penelitian ini menambahkan variabel perceived risk sebagai variabel mediasi pada hubungan antara EWOM negatif terhadap niat pembelian. Menurut Erkan \& Evans (2016), kualitas, kredibilitas, kegunaan dan adopsi informasi, kebutuhan informasi dan sikap terhadap informasi adalah faktor kunci EWOM di media sosial yang memengaruhi niat beli konsumen. Perceived risk juga diperlukan untuk mengetahui seberapa besar risiko yang dihadapi konsumen atas suatu sistem informasi yang telah dibentuk. Menurut Schiffman dan Kanuk (2008:137), risiko yang dirasakan didefinisikan sebagai ketidakpastian yang dihadapi para konsumen jika mereka tidak dapat meramalkan konsekuensi keputusan pembelian mereka. Sedangkan menurut Suhir, Imam, dan Riyandi (2014:4), perceived risk diartikan sebagai penilaian subjektif oleh seseorang terhadap kemungkinan dari sebuah kejadian kecelakaan dan seberapa khawatir individu dengan konsekuensi atau dampak yang ditimbulkan kejadian tersebut. Menurut Martinez \& Kim (2012; dalam Hananda, 2019), niat beli merupakan tahap kecenderungan konsumen untuk bertindak sebelum benar-benar melakukan pembelian. Sedangkan Tamizhvanan dan Xavier (2013) mendefinisikan niat belanja online sebagai keinginan pada diri konsumen untuk melakukan pembelian secara online. Ada efek positif dari konstruksi TAM utama (yaitu manfaat yang dirasakan dan kemudahan penggunaan) dan kepercayaan pada niat beli (Ahn et. al, 2014).

Menurut pra survei penelitian yang dilakukan, dari 47 responden sejumlah 25 responden menyatakan terdapat risiko jika melakukan pembelian jasa layanan kesehatan online Halodoc. Namun, aplikasi Halodoc masih banyak diminati dengan adanya bukti bahwa dari 48 responden, sejumlah 57,4\% masih tetap memilih Halodoc dibandingkan aplikasi jasa layanan kesehatan lainnya, sedangkan 42,6\% lebih memilih aplikasi lain dibandingkan dengan Halodoc. Hal ini berbanding terbalik dengan teori yang dikemukakan oleh Arun dan Xavier (2012:20) dalam Haekal dan Widjajanta, yaitu semakin berisikonya pembelian online maka konsumen akan tidak berminat, tetapi apabila risiko rendah maka konsumen akan lebih berminat membeli secara online.

Salah satu aplikasi yang bergerak di bidang layanan kesehatan online yaitu Halodoc. Halodoc adalah aplikasi yang bergerak di bidang layanan kesehatan online di bawah naungan PT. Media Dokter Investama. Halodoc menawarkan berbagai jasa layanan seperti konsultasi online, pengiriman obat, tes laboratorium on-demand, direktori rumah sakit dan dokter, serta penjadwalan. Konsultasi medis yang 
Ursila Imro'atu Wakhida dan Sanaji. Peran Perceived Usefulness dan Perceived Risk sebagai Variabel Pemediasi pada Pengaruh Perceived Ease of Use dan e-WOM Negatif terhadap Niat Pembelian Para Pengguna Aplikasi Layanan Kesehatan Halodoc

dilakukan antara dokter dan user menggunakan fitur video call (teleconsultation). Saat ini tercatat ada sepuluh start up kesehatan terbaik di Indonesia, antara lain Halodoc, Alodokter, Dokter.ID, Klikdokter, Tanyadok, DokterSehat, Konsula, Medika App, Go Dok, Medicaboo (Maulana, 2017). Beberapa start up kesehatan tersebut memiliki perbedaan di antaranya adalah dalam hal jenis layanan yang diberikan oleh masing-masing perusahaan.

Lima variabel yang di eksplorasi adalah perceived ease of use, EWOM negatif, perceived usefulness, perceived risk, dan niat pembelian konsumen. Konstruk perceived ease of use merupakan suatu kepercayaan tentang proses pengambilan keputusan dimana seseorang percaya bahwa dengan menggunakan sebuah teknologi akan bebas dari usaha (Davis, 1989; Eriska, 2018). Selain itu keyakinan konsumen tentang sejauh mana ia akan menjadi lebih baik dari transaksi online dengan aplikasi tertentu (Davis, 1989; Kim, et.al, 2008; Eriska, 2018). Dari terbentuknya perceived ease of use dan perceived usefulness, konsumen memiliki penilaian subjektif terhadap kemungkinan dari sebuah kejadian kecelakaan dan seberapa khawatir individu dengan konsekuensi atau dampak yang ditimbulkan kejadian tersebut (Schiffman dan Kanuk, 2008:137; Suhir, Suyadi, dan Riyadi, 2014:4; Haekal dan Widjajanta, 2016:186). Selain itu, Tingginya aktivitas EWOM akan menurunkan persepsi risiko konsumen sehingga mendorong niat pembelian secara online (Indiani et.al, 2015; Erkan \& Evans, 2016). Namun demikian, bagaimana konsistensi hubungan kelima variabel tersebut belum diketahui dengan jelas. Artikel yang membahas tentang konsistensi hubungan kelima variabel tersebut masih sedikit. Sehingga, perlu dilakukan analisis jalur (path analysis) untuk memahami bagaimana konsistensi hubungan antara kelima variabel tersebut untuk mendapatkan pemahaman baru dalam penerimaan teknologi informasi dibandingkan dengan beberapa penelitian sebelumnya yang hanya menerapkan teori TAM antara lain perceived ease of use, dan perceived usefulness pada niat pembelian sebuah aplikasi jasa layanan.

Penelitian ini bertujuan untuk mengetahui tingkat penerimaan sistem informasi yang digunakan di aplikasi layanan kesehatan online Halodoc yang dianalisis menggunakan model teori TRITAM.

\section{KAJIAN PUSTAKA DAN PENGEMBANGAN HIPOTESIS}

\section{Technology Acceptance Model (TAM)}

Technology Acceptance Model (TAM) adalah model yang disusun oleh Davis (1989) dan dikembangkan lagi oleh beberapa peneliti seperti Adams et. al. (1992), Szajna (1994), Igbaria et. al. (1995), Venkatesh \& Morris (2000), Venkatesh \& Davis (2000), dan Sanjaya (2005) untuk menjelaskan penerimaan teknologi yang akan digunakan oleh pengguna teknologi. Model ini pertama kali diperkenalkan oleh Fred Davis pada tahun 1986. Modifikasi model TAM dilakukan oleh Venkatesh et.al, (2002) dengan menambahkan variabel trust dengan judul: Trust enhanced Technology Acceptance Model, yang meneliti tentang hubungan antar variabel TAM dan trust seperti yang terlihat di Gambar 1. Modifikasi TAM lain yaitu Trust and Risk in Technology Acceptance Model (TRITAM) yang menggunakan variabel kepercayaan dan risiko bersama variabel TAM seperti yang dapat dilihat di Gambar 2 (Lui \& Jamieson, 2003).

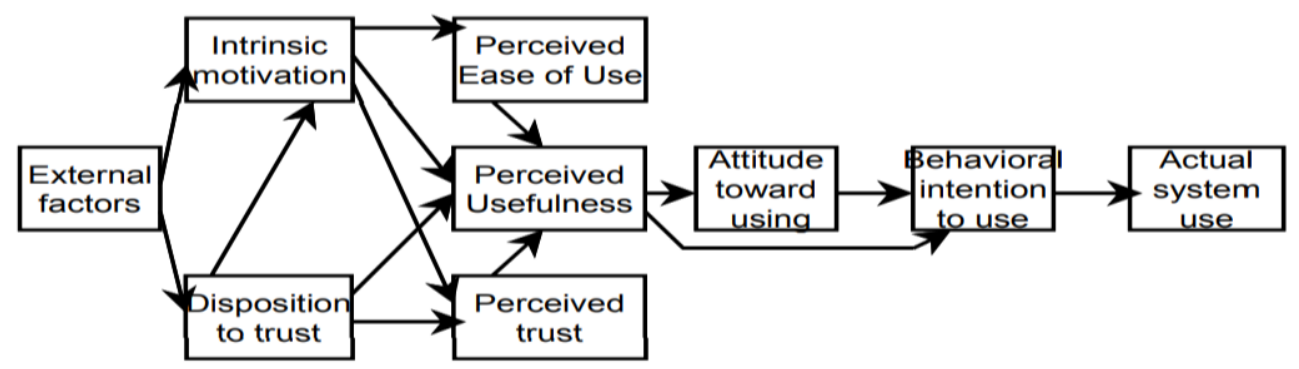

Sumber: Venkatesh et.al, (2002)

Gambar 1. TRUST ENHANCED TECHNOLOGY ACCEPTANCE MODEL 


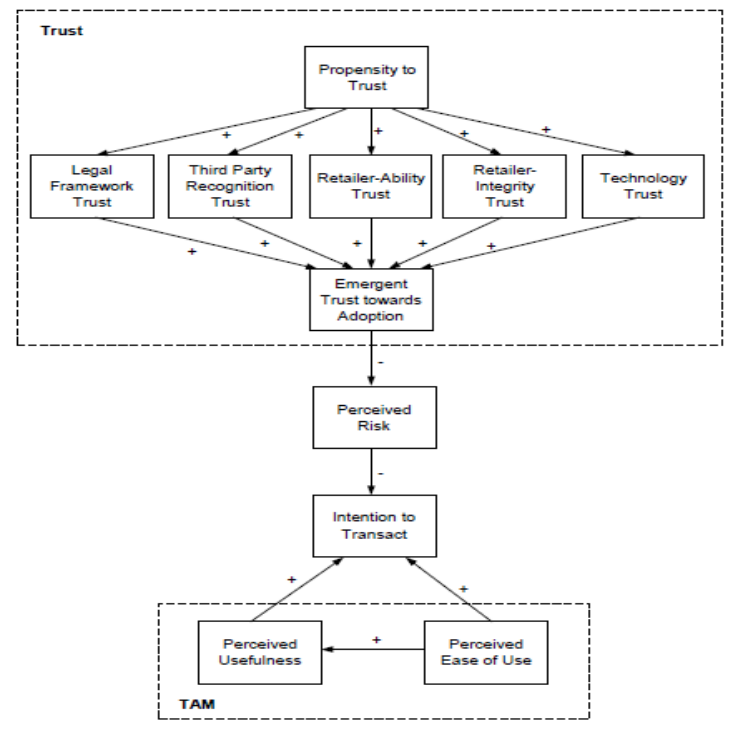

Sumber: Lui \& Jamieson (2003)

\section{Gambar 2. TRUST AND RISK IN TECHNOLOGY ACCEPTANCE MODEL (TRITAM)}

Ada tiga faktor yang memengaruhi penggunaan sebuah sistem sesuai yang diusulkan oleh Fred Davis yaitu (1) perceived usefulness, (2) perceived ease of use, dan (c) intention to use. Menurut pengertian beberapa ahli, TAM merupakan model teori yang digunakan untuk memprediksi seberapa besar penerimaan teknologi informasi yang dirasakan oleh pengguna (konsumen). Terdapat dua komponen yang terbukti berpengaruh, yaitu perceived ease of use terhadap perceived usefulness.

\section{Perceived Ease of Use}

Perceived ease of use merupakan suatu tingkat keyakinan seseorang bahwa dengan menggunakan sistem atau aplikasi tertentu tidak diperlukan usaha apapun (free of effort) atau teknologi tersebut dapat dengan mudah dipahami oleh pengguna (Davis, 1989). Menurut Damayanti (2019), perceived ease of use adalah persepsi yang dirasakan konsumen mengenai mudahnya penggunaan, pengoperasian sistem aplikasi yang dirancang agar konsumen tidak merasa kesulitan saat berbelanja secara online. Penggunaan aplikasi mempercayai bahwa aplikasi yang lebih fleksibel, mudah dipahami dan mudah pengoperasiannya sebagai karakteristik kemudahan penggunaan. Aplikasi yang lebih sering digunakan menunjukkan bahwa sistem tersebut lebih dikenal, lebih mudah dioperasikan dan lebih mudah digunakan oleh penggunanya (Adams, et.al, 1992). Menurut pernyataan beberapa ahli, perceived ease of use merupakan persepsi kemudahan penggunaan teknologi dan internet yang dirasakan oleh konsumen tanpa mengeluarkan suatu usaha apapun dalam mengoperasikan sistem aplikasi yang dirancang untuk memudahkan konsumen. Pengukuran variabel perceived ease of use dalam penelitian ini menggunakan indikator dari Davis (1989) yang disesuaikan dengan objek penelitian yaitu mudah dipelajari (easy to learn), terkendali (controllable), serta jelas dan dapat dipahami (clear \& understandable). Menurut Eriska (2018), terdapat pengaruh tidak langsung yang signifikan antara perceived ease of use terhadap intention melalui perceived of usefulness. Perceived ease of use tidak begitu berpengaruh dalam membentuk niat penggunaan (Kucukusta et. al, 2015). Ada efek positif dari konstruksi TAM utama (yaitu manfaat yang dirasakan dan kemudahan penggunaan) dan kepercayaan pada niat beli (Ahn et. al, 2014).

\section{Perceived Usefulness}

Perceived usefulness adalah sejauh mana seseorang percaya bahwa menggunakan suatu teknologi akan meningkatkan kinerjanya (Davis, 1989). Persepsi manfaat dalam e-commerce merupakan keyakinan konsumen tentang sejauh mana ia akan menjadi lebih baik dari transaksi online dengan aplikasi tertentu (Kim, et.al, 2008). Menurut pernyataan beberapa ahli, perceived usefulness merupakan tingkat kinerja dari kegunaan internet dan teknologi dalam melakukan kegiatan sehari-hari. Penelitian ini menggunakan indikator menurut Davis (1989) dalam jurnal Fatmawati, yaitu mempercepat konsultasi kesehatan, mengatasi kebutuhan, meningkatkan produktivitas (increase productivity), efektifitas 
Ursila Imro'atu Wakhida dan Sanaji. Peran Perceived Usefulness dan Perceived Risk sebagai Variabel Pemediasi pada Pengaruh Perceived Ease of Use dan e-WOM Negatif terhadap Niat Pembelian Para Pengguna Aplikasi Layanan Kesehatan Halodoc

(effectiveness), mempermudah pekerjaan (make job easier), dan bermanfaat (useful). Menurut Eriska (2018), terdapat pengaruh yang signifikan antara perceived of usefulness terhadap intention. Terdapat pengaruh tidak langsung yang signifikan antara perceived ease of use terhadap intention melalui perceived of usefulness. Menurut Kucukusta et. al (2015), manfaat yang dirasakan dari internet ditemukan lebih berpengaruh daripada kemudahan penggunaannya dalam membentuk niat penggunaan. Ada efek positif dari konstruksi TAM utama (yaitu manfaat yang dirasakan dan kemudahan penggunaan) dan kepercayaan pada niat beli (Ahn et. al, 2014).

\section{Perceived Risk}

Perceived risk adalah sebuah ketidakpastian yang dihadapi oleh konsumen dalam berbelanja online. Menurut Hawkins \& Mothersbaugh (2010:600) dalam Haekal dan Widjajanta, perceived risk dianggap sebagai karakteristik dari konsumen serta karakteristik produk itu sendiri. Menurut Schiffman \& Kanuk (2008:137), risiko yang dirasakan didefinisikan sebagai ketidakpastian yang dihadapi para konsumen jika mereka tidak dapat meramalkan konsekuensi keputusan pembelian mereka. Sedangkan menurut Suhir, Suyadi, dan Riyadi (2014:4), perceived risk diartikan sebagai penilaian subjektif oleh seseorang terhadap kemungkinan dari sebuah kejadian kecelakaan dan seberapa khawatir individu dengan konsekuensi atau dampak yang ditimbulkan kejadian tersebut. Selain itu, penelitian lain telah mengungkapkan bahwa perceived risk berhubungan negatif dengan perceived usefulness atau perceived ease of use sebelum membeli produk atau layanan (Li \& Huang, 2009). Tingginya aktivitas EWOM akan menurunkan persepsi risiko konsumen sehingga mendorong minat pembelian secara online (Indiani et.al, 2015). Oleh sebab itu, pada penelitian ini di tambahkan variabel perceived risk sebagai variabel mediasi pada hubungan antara EWOM negatif terhadap niat pembelian. Menurut pernyataan beberapa ahli, perceived risk merupakan perasaan kekhawatiran yang dirasakan oleh konsumen sebagai akibat dari hasil penggunaan sebuah teknologi informasi. Penelitian ini menggunakan dimensi menurut Hoyer \& Maclnnis (2010:59-60), Forsythe et al. (2006), Javadi et al. (2012) dalam Abi dan Wismiarsi sebagai alat ukur penelitian, yaitu risiko kinerja, risiko keuangan/ transaksi, risiko waktu, risiko pengiriman, dan risiko psikologis.

\section{EWOM Negatif}

Menurut Schiffman \& Kanuk (2010), EWOM sebagai Word Of Mouth yang dilakukan secara online. Menurut Hananda (2019:24), EWOM sebagai sebuah media komunikasi untuk saling berbagi informasi mengenai suatu produk atau jasa yang telah dikonsumsi antar konsumen yang tidak saling mengenal dan bertemu sebelumnya. Media komunikasi dalam hal ini adalah internet. Menurut Hananda (2019), proses komunikasi antar konsumen melalui internet dikenal dengan Electronic Word Of Mouth (EWOM). Menurut Humaira dan Wibowo (2016), media elektronik memberikan manfaat sebagai wadah untuk saling berbagi foto, video ke blog pribadi, memberikan rating, mengevaluasi, melihat peta secara online dan sebagainya untuk berbagi dan merekomendasikan kepada sesama pengguna. Menurut pernyataan beberapa ahli, EWOM merupakan media komunikasi untuk bertukar informasi mengenai suatu produk atau jasa. Penelitian ini memilih untuk menggunakan dimensi menurut Goyette et al., (2010:11) yaitu intensitas, konten, pendapat positif, pendapat negatif.

\section{Niat Beli}

Menurut Hananda (2019), niat beli merupakan tahap kecenderungan konsumen untuk bertindak sebelum benar-benar melakukan pembelian. Namun disisi lain, niat pembelian online didefinisikan sebagai situasi ketika konsumen memiliki keinginan untuk membeli produk atau jasa melalui situs web (Chen, Hsu, \& Lin, 2010). Menurut Pearson \& Miller (2001) dalam Kwek et al, konsumen yang mempunyai niat membeli secara online dalam lingkungan situs berbelanja akan menentukan niat seseorang untuk melakukan pembelian yang ditentukan perilaku melalui internet. Niat beli online dalam hal ini diartikan bahwa konsumen telah memiliki kemampuan dan pengetahuan untuk bertransaksi online. Sedangkan Tamizhvanan \& Xavier (2013) mendefinisikan niat belanja online sebagai keinginan pada diri konsumen untuk melakukan pembelian secara online. Berdasarkan pengertian beberapa ahli, niat beli konsumen berarti konsumen telah memiliki keinginan untuk melakukan pembelian dari dalam diri sendiri serta mengacu pada hasil pencarian informasi yang telah didapatkan sampai pada tahap evaluasi terhadap produk atau jasa juga perusahaan sebelum benar-benar melakukan pembelian. Pada 
penelitian ini, indikator diambil menurut Schiffman \& Kanuk (2010) dan Ling et.al, (2010) yaitu (1) tertarik untuk mencari informasi mengenai produk, (2) mempertimbangkan untuk membeli, (3) tertarik untuk mencoba, dan (4) keinginan untuk melakukan pembelian dalam waktu dekat.

\section{Hubungan antar Variabel}

Menurut Eriska (2018), terdapat pengaruh yang signifikan antara perceived ease of use terhadap perceived usefulness. Terdapat pengaruh tidak langsung yang signifikan antara perceived ease of use terhadap intention melalui perceived of usefulness. Sedangkan menurut Santoso (2010), Variabel perceived ease of use (PEOU) terbukti berpengaruh signifikan terhadap variabel perceived usefulness (PU).

\section{H1: Perceived ease of use berpengaruh positif terhadap perceived usefulness.}

Menurut Kucukusta et. al (2015), manfaat yang dirasakan dari internet ditemukan lebih berpengaruh daripada kemudahan penggunaannya dalam membentuk niat penggunaan. Menurut Santoso (2010), faktor yang secara langsung memengaruhi penerimaan STI adalah perceived usefulness (PU) yang didefinisikan sebagai persepsi pengguna tentang STI dan secara tidak langsung di pengaruhi oleh perceived ease of use (PEOU) dan perceived enjoyment (PE) yang didefinisikan sebagai kemudahan dan kenyamanan dalam menggunakan STI. Menurut Ahn et. al (2014), ada efek positif dari konstruksi TAM utama (yaitu manfaat yang dirasakan dan kemudahan penggunaan) dan kepercayaan pada niat beli.

H2: Perceived usefulness berpengaruh positif terhadap niat pembelian.

Menurut Damayanti (2019), perceived ease of use atau kemudahan pengguna dalam menggunakan sistem informasi yang digunakan yaitu jual beli online. Usaha yang dikeluarkan dalam jual beli online tidak terlalu banyak dan tidak terlalu menghabiskan tenaga sehingga jika efektif maka pengguna cenderung menggunakan sistem belanja online. Menurut Eriska (2018), terdapat pengaruh tidak langsung yang signifikan antara perceived ease of use terhadap intention melalui perceived of usefulness. Menurut Kucukusta et. al (2015), perceived ease of use tidak begitu berpengaruh dalam membentuk niat penggunaan. Menurut Santoso (2010), faktor yang secara tidak langsung di pengaruhi oleh perceived ease of use (PEOU) dan perceived enjoyment (PE) yang didefinisikan sebagai kemudahan dan kenyamanan dalam menggunakan STI. Menurut Ahn et. al (2014), ada efek positif dari konstruksi TAM utama (yaitu manfaat yang dirasakan dan kemudahan penggunaan) dan kepercayaan pada niat beli. Sehingga, riset gap tersebut merupakan alasan perlu adanya variabel mediasi.

\section{H3: Perceived ease of use tidak berpengaruh langsung terhadap niat pembelian.}

Menurut Indiani et. al (2015), aktivitas EWOM memiliki pengaruh negatif terhadap persepsi risiko konsumen yang akan melakukan pembelian produk secara online. Persepsi risiko memediasi hubungan EWOM dengan minat beli konsumen. Informasi yang diberikan melalui EWOM kemudian digunakan sebagai pertimbangan bagi konsumen sebelum melakukan pembelian produk. Tingginya aktivitas EWOM akan menurunkan persepsi risiko konsumen. Sedangkan menurut Eriza (2017), EWOM berpengaruh negatif terhadap persepsi risiko namun tidak memediasi hubungan EWOM dan minat beli. Ada sejumlah besar bukti yang menunjukkan bahwa pengaruh informasi WOM negatif lebih kuat dibandingkan dengan informasi WOM positif dalam memengaruhi niat pembelian pembeli potensial (Brown \& Reingen, 1987; Weinberger, Allen dan Dillon, 1980; dalam Chatterjee, 2001). Namun, karena arti penting informasi WOM negatif pada niat beli akan tergantung pada persepsi konsumen tentang generalisasi dan kemungkinan terulangnya risiko kegagalan layanan, sehingga penelitian ini memilih menggunakan perceived risk sebagai variabel mediasi. 
Ursila Imro'atu Wakhida dan Sanaji. Peran Perceived Usefulness dan Perceived Risk sebagai Variabel Pemediasi pada Pengaruh Perceived Ease of Use dan e-WOM Negatif terhadap Niat Pembelian Para Pengguna Aplikasi Layanan Kesehatan Halodoc

\section{H4: EWOM negatif berpengaruh positif terhadap perceived risk.}

Menurut Haekal \& Widjajanta (2016), kepercayaan dan persepsi risiko berpengaruh secara simultan terhadap minat membeli secara online. Sedangkan pengaruh secara parsial menunjukan bahwa dimensi benevolence dan dimensi risiko kinerja memiliki pengaruh yang lebih besar dibandingkan dengan dimensi lainya. Berdasarkan hasil penelitian melalui linear berganda terdapat pengaruh yang signifikan dari kepercayaan dan persepsi risiko terhadap minat membeli secara online. Menurut Rosian dan Wijaya (2016), semakin tinggi kepercayaan konsumen terhadap situs belanja online akan mengurangi risiko yang konsumen rasakan dalam bertransaksi secara online. Studi ini tidak membuktikan adanya pengaruh yang signifikan antara risiko dengan minat beli belanja online. Menurut Indiani et. al (2015), persepsi risiko memiliki pengaruh negatif terhadap niat beli. Menurut Eriza (2017), persepsi risiko berpengaruh signifikan pada niat membeli konsumen. Sebaliknya persepsi risiko yang rendah membuat seseorang tidak merasa takut dalam melakukan transaksi online. Hubungan antar variabel dalam penelitian ini juga digambarkan di Gambar 3.

H5: Perceived risk berpengaruh positif terhadap niat pembelian.

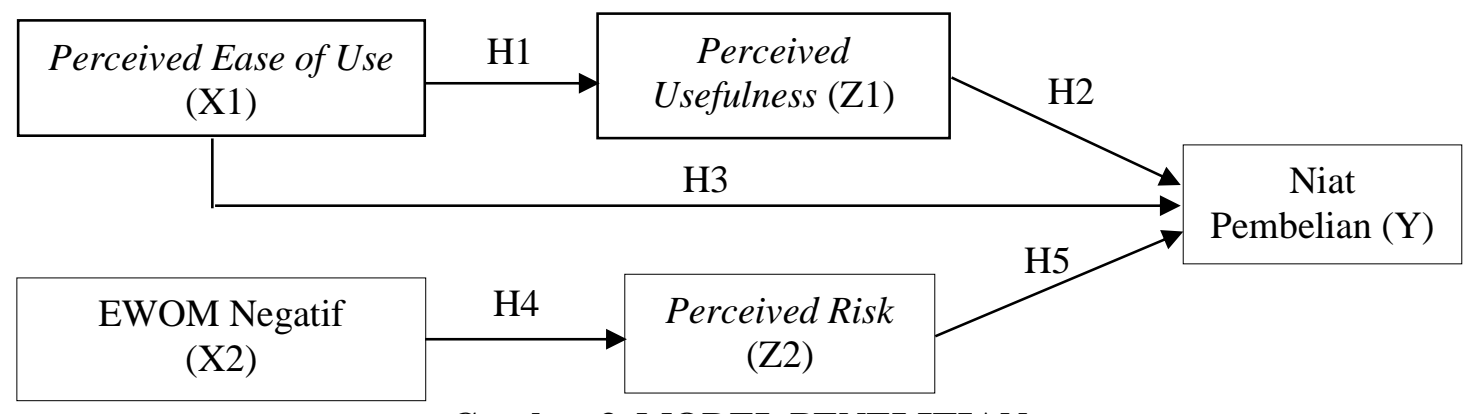

Gambar 3. MODEL PENELITIAN

\section{METODE PENELITIAN}

Jenis penelitian ini adalah penelitian konklusif dengan tujuan untuk mendapatkan bukti antar variabel yang dihoptesiskan. Jumlah sampel ditetapkan sebanyak 200 sampel didasarkan bahwa jumlah sampel yang digunakan untuk pengujian pasar adalah 200 sampel (Malhotra, 2017:369). Sampel yang digunakan adalah masyarakat yang tinggal di Jawa Timur yang ditarik secara purposive dengan kriteria berusia 21->50 tahun, belum pernah menggunakan namun mengetahui aplikasi Halodoc dan pernah membaca ulasan/ berita/ iklan tentang Halodoc.

Instrument penelitian menggunakan kuesioner dirancang untuk mengukur persepsi kemudahan penggunaan, persepsi manfaat, EWOM negatif, persepsi risiko, dan niat pembelian. Indikator persepsi penggunaan merujuk Davis (1989) dalam Fatmawati Endang untuk mengindikasikan tingkat kemudahan penggunaan yang dipersepsikan konsumen, apakah teknologi informasi dapat diterima atau tidak oleh konsumen. EWOM diukur dengan empat item pernyataan merujuk Hananda (2019), antara lain sering membaca review online aplikasi Halodoc untuk mengetahui jenis layanan yang paling baik. Perceived usefulness diukur dengan enam item pernyataan merujuk Davis (1989) dalam Fatmawati, antara lain menggunakan aplikasi Halodoc menghemat waktu. Perceived risk diukur dengan sepuluh item pernyataan merujuk Suhir, Imam, dan Riyandi (2014), antara lain kekhawatiran hasil diagnosa dokter tidak tepat. Niat beli diukur dengan lima item, tiga item dari Schiffman \& Kanuk (2010) dan dua item dari Ling et.al, (2010), antara lain responden akan menggunakan layanan Halodoc di waktu yang akan datang. Masing-masing item pernyataan dari perceived ease of use, EWOM negatif, perceived usefulness, perceived risk, dan niat beli di rancang menggunakan teknik penskalaan Likert lima point dari "sangat tidak setuju" nilai 1 sampai "sangat setuju" nilai 5. Item pernyataan dan hasil uji validitas dan reliabilitasnya secara lengkap disajikan di Tabel 2. Selanjutnya, data di analisis menggunakan metode statistik deskriptif (rata-rata dan distribusi frekuensi). Untuk menguji hipotesis digunakan analisis jalur yang diolah dengan pengolah data AMOS versi 22. 


\section{HASIL DAN PEMBAHASAN}

\section{Uji Validitas dan Reliabilitas}

Hasil pengujian validitas dan reliabilitas dapat di olah dari nilai correlated item total. Jika koefisien antara item dengan total item sama atau diatas 0,3 maka item tersebut dinyatakan valid, tetapi jika nilai korelasinya di bawah 0,3 maka item tersebut dinyatakan tidak valid (Sugiyono, 2016:177). Sehingga item pernyataan atau indikator dapat dikatakan valid apabila nilai correlated item total $\geq 0,3$ dan nilai cronbach's alpha $>0,70$. Selanjutnya hasil uji analisa validitas dan reliabilitas menunjukkan bahwa semua item pada kuesioner terbukti valid, namun ada satu variabel terbukti tidak reliabel (Tabel 2).

Berdasarkan Tabel 2, terdapat empat variabel dalam penelitian ini mempunyai nilai cronbach's alpha lebih dari 0,7 yaitu variabel perceived ease of use, perceived usefulness, perceived risk, dan niat pembelian. Sedangkan pada variabel EWOM negatif memiliki nilai cronbach's alpha kurang dari 0,7. Sehingga, item pernyataan pada keempat variabel diatas dinyatakan valid dan reliabel. Namun, item pada variabel EWOM negatif dinyatakan valid tetapi tidak reliabel.

Tabel 1.

DISTRIBUSI FREKUENSI KARAKTERISTIK RESPONDEN

\begin{tabular}{llcc}
\hline \multicolumn{2}{c}{ Karakteristik Responden } & Frekuensi & Persentase (\%) \\
\hline \multirow{3}{*}{ Jenis Kelamin } & Laki-laki & 49 & $24,5 \%$ \\
& Perempuan & 151 & $75,5 \%$ \\
& 21 - 25 Tahun & 178 & $89 \%$ \\
& 26 - 30 Tahun & 10 & $5 \%$ \\
& 31 - 35 Tahun & 7 & $3.50 \%$ \\
& 36 - 40 Tahun & 1 & $0.50 \%$ \\
& 41 - 45 Tahun & 2 & $1 \%$ \\
& 46 - 50 Tahun & 1 & $0.50 \%$ \\
Pekerjaan & $>$ 50 Tahun & 1 & $0.50 \%$ \\
& Pelajar/ Mahasiswa & 121 & $60.50 \%$ \\
& Karyawan Swasta & 39 & $19.50 \%$ \\
& Pegawai Negeri & 1 & $0.50 \%$ \\
& Wirausaha & 14 & $7 \%$ \\
Pendapatan & Lain-lain & 25 & $12.50 \%$ \\
& < Rp 1.000.000 & 117 & $58.50 \%$ \\
& Rp 1.000.001 - Rp 2.000.000 & 33 & $16.50 \%$ \\
& Rp 2.000.001 - Rp 3.000.000 & 17 & $8.50 \%$ \\
& Rp 3.000.001 - Rp 4.000.000 & 15 & $7.50 \%$ \\
& Rp 4.000.001 - Rp 5.000.000 & 7 & $3.50 \%$ \\
& $>$ Rp 5.000.000 & 11 & $5.50 \%$ \\
\hline Total & & 200 & $100 \%$ \\
\hline
\end{tabular}

Sumber: Data diolah

\section{Profil Responden}

Berdasarkan Tabel 1, sebagian besar responden berjenis kelamin perempuan dengan jumlah 151 orang $(75,7 \%)$. Berdasarkan usia, responden paling banyak berusia 21-25 tahun yaitu 178 orang (89\%). Mayoritas responden berstatus sebagai pelajar/mahasiswa dengan jumlah 121 orang (60,5\%). Rata-rata penghasilan responden yang paling banyak berkisar $<\mathrm{Rp} 1.000 .000,00$ dengan jumlah 117 orang $(58,5 \%)$. 
Ursila Imro'atu Wakhida dan Sanaji. Peran Perceived Usefulness dan Perceived Risk sebagai Variabel Pemediasi pada Pengaruh Perceived Ease of Use dan e-WOM Negatif terhadap Niat Pembelian Para Pengguna Aplikasi Layanan Kesehatan Halodoc

Tabel 2.

HASIL UJI VALIDITAS DAN RELIABILITAS

\begin{tabular}{|c|c|c|c|}
\hline No & Pernyataan & $\begin{array}{l}\text { Correlated } \\
\text { Item-Total }\end{array}$ & $\begin{array}{l}\text { Cronbach's } \\
\text { Alpha }\end{array}$ \\
\hline \multicolumn{4}{|c|}{ Perceived ease of use } \\
\hline 1 & Aplikasi Halodoc menyediakan kemudahan dalam proses pemesanan & 0,332 & \multirow{5}{*}{0.791} \\
\hline 2 & Aplikasi Halodoc menyediakan kemudahan dalam proses pembayaran & 0,346 & \\
\hline 3 & Konsultasi mudah dipantau melalui smartphone & 0,305 & \\
\hline & $\begin{array}{l}\text { Aplikasi Halodoc memberikan keterangan lengkap cara penggunaan } \\
\text { aplikasi }\end{array}$ & 0,443 & \\
\hline 5 & Pengoperasian aplikasi sudah jelas & 0,401 & \\
\hline \multicolumn{4}{|c|}{ Electronic word of mouth (EWOM) negatif } \\
\hline 6 & $\begin{array}{l}\text { Sering membaca review online aplikasi Halodoc untuk mengetahui jenis } \\
\text { layanan yang paling baik }\end{array}$ & 0,413 & \multirow{4}{*}{0,570} \\
\hline 7 & $\begin{array}{l}\text { Sering mencari keterangan lewat review online aplikasi Halodoc untuk } \\
\text { membantu memilih jasa yang benar }\end{array}$ & 0,436 & \\
\hline 8 & $\begin{array}{l}\text { Saya ragu menggunakan aplikasi Halodoc, sebelum membaca review } \\
\text { online terkait aplikasi ini }\end{array}$ & 0,385 & \\
\hline 9 & $\begin{array}{l}\text { Review online aplikasi Halodoc menambah keyakinan niat pembelian } \\
\text { saya }\end{array}$ & 0,413 & \\
\hline \multicolumn{4}{|c|}{ Perceived usefulness } \\
\hline 10 & Menggunakan aplikasi Halodoc menghemat waktu saya & 0,309 & \multirow{6}{*}{0,870} \\
\hline 11 & Menggunakan aplikasi Halodoc memenuhi kebutuhan kesehatan saya & 0,390 & \\
\hline 12 & $\begin{array}{l}\text { Menggunakan aplikasi Halodoc lebih cepat dalam berkonsultasi } \\
\text { kesehatan }\end{array}$ & 0,509 & \\
\hline 13 & $\begin{array}{l}\text { Menggunakan aplikasi Halodoc lebih efektif dalam berkonsultasi } \\
\text { kesehatan }\end{array}$ & 0,523 & \\
\hline 14 & $\begin{array}{l}\text { Menggunakan aplikasi Halodoc memudahkan pekerjaan dalam hal } \\
\text { konsultasi kesehatan }\end{array}$ & 0,404 & \\
\hline 15 & $\begin{array}{l}\text { Secara keseluruhan, selama penggunaan aplikasi Halodoc bermanfaat } \\
\text { dalam konsultasi kesehatan }\end{array}$ & 0,431 & \\
\hline \multicolumn{4}{|c|}{ Perceived risk } \\
\hline 16 & Saya khawatir hasil diagnosa dokter tidak tepat & 0,393 & \multirow{10}{*}{0,922} \\
\hline 17 & $\begin{array}{l}\text { Saya khawatir pemberian informasi yang kurang jelas dari dokter } \\
\text { menimbulkan kesalahan penafsiran }\end{array}$ & 0,423 & \\
\hline 18 & Saya khawatir kartu pembayaran yang saya miliki tidak aman lagi & 0,543 & \\
\hline 19 & Saya khawatir aplikasi Halodoc dapat menjual jasa dan obat lebih mahal & 0,497 & \\
\hline 20 & Saya khawatir jangka waktu pengiriman obat lama & 0,436 & \\
\hline 21 & Saya khawatir tidak menerima obat yang sudah dibeli secara online & 0,488 & \\
\hline 22 & Saya khawatir pengiriman produk menuju tempat yang salah & 0,517 & \\
\hline 23 & $\begin{array}{l}\text { Saya khawatir pengiriman tidak sesuai dengan waktu yang sudah } \\
\text { ditentukan }\end{array}$ & 0,496 & \\
\hline 24 & $\begin{array}{l}\text { Saya akan rugi jika memberi informasi pribadi pada aplikasi layanan } \\
\text { kesehatan online Halodoc }\end{array}$ & 0,480 & \\
\hline 25 & $\begin{array}{l}\text { Saya khawatir informasi kesehatan yang tersedia menimbulkan banyak } \\
\text { permasalahan yang tidak diduga }\end{array}$ & 0,558 & \\
\hline \multicolumn{4}{|c|}{ Niat pembelian } \\
\hline 26 & $\begin{array}{l}\text { Saya akan menggunakan layanan Halodoc, ketika menemukan layanan } \\
\text { yang saya sukai }\end{array}$ & 0,608 & \multirow{5}{*}{0,812} \\
\hline 27 & $\begin{array}{l}\text { Saya bersedia membeli jasa layanan di aplikasi Halodoc daripada yang } \\
\text { lain }\end{array}$ & 0,465 & \\
\hline 28 & Saya tertarik mencoba jenis layanan jasa kesehatan di aplikasi Halodoc & 0,555 & \\
\hline 29 & $\begin{array}{l}\text { Saya mau mempertimbangkan membeli jasa layanan kesehatan di aplikasi } \\
\text { Halodoc untuk diri saya pada waktu dekat }\end{array}$ & 0,497 & \\
\hline 30 & Saya akan membeli jasa layanan Halodoc di waktu dekat & 0,442 & \\
\hline
\end{tabular}

Sumber: Data diolah 
Berdasarkan hasil penelitian ini, rata-rata variabel perceived ease of use adalah sebesar 3,81 dan dapat dikategorikan setuju. Hal ini menunjukkan bahwa rata-rata responden yang merasakan adanya kemudahan penggunaan pada aplikasi layanan kesehatan Halodoc membenarkan bahwa terjadi pengaruh perceived ease of use. Responden merasa bahwa perceived ease of use memiliki peranan yang penting agar mereka dapat membeli jasa pada aplikasi layanan kesehatan Halodoc. Rata-rata penilaian variabel EWOM neagtif adalah sebesar 3,51 dan dapat di kategorikan setuju. Hal ini menunjukkan bahwa rata-rata responden yang merasakan EWOM negatif dari penggunaan aplikasi layanan kesehatan Halodoc membenarkan bahwa terjadi pengaruh EWOM negatif. Responden merasa bahwa EWOM negatif memiliki peranan penting agar mereka dapat membeli jasa pada aplikasi layanan kesehatan Halodoc. Selanjutnya rata-rata variabel perceived usefulness adalah sebesar 3,77 dan dapat di kategorikan setuju. Hal ini menunjukkan bahwa rata-rata responden yang merasakan adanya manfaat dari aplikasi layanan kesehatan Halodoc membenarkan bahwa terjadi pengaruh perceived usefulness. Responden merasa bahwa perceived usefulness memiliki peranan yang penting agar mereka dapat membeli jasa pada aplikasi layanan kesehatan Halodoc. Rata-rata penilaian variabel perceived risk adalah sebesar 2,96 dan dapat di kategorikan cukup setuju. Hal ini menunjukkan bahwa rata-rata responden yang merasakan adanya risiko pada aplikasi layanan kesehatan Halodoc membenarkan bahwa terjadi pengaruh perceived risk. Responden merasa bahwa perceived risk memiliki peranan yang cukup penting agar mereka dapat membeli jasa pada aplikasi layanan kesehatan Halodoc. Kemudian yang terakhir adalah rata-rata variabel niat pembelian sebesar 3,38 dan dapat di kategorikan cukup setuju. Hal ini menunjukkan bahwa rata-rata responden yang menggunakan aplikasi layanan kesehatan Halodoc membenarkan bahwa mereka memiliki niat untuk membeli jasa pada aplikasi layanan kesehatan Halodoc. Responden merasa bahwa ketika mereka menggunakan aplikasi layanan kesehatan Halodoc niatan untuk membeli jasa pada aplikasi layanan kesehatan Halodoc muncul.

\section{Uji Asumsi Analisis Jalur}

Analisis jalur mensyaratkan variabel berdistribusi normal dan tidak mengandung outlier. Uji normalitas dilakukan baik secara univariat maupun multivariat menggunakan nilai critical skeweness dan kurtosis. Hasil uji normalitas membuktikan bahwa dari lima variabel yang di uji telah berdistribusi normal di lihat dari nilai critical ratio skewness value tiap variabel yaitu EWOM negatif sebesar -1,335, perceived ease of use sebesar $-1,945$, perceived risk sebesar 0,115 , perceived usefulness sebesar -0,459, dan niat pembelian sebesar $-0,155$ berada di antara $-2,58$ sampai $\pm 2,58$. Kemudian juga di lihat dari uji normalitas multivariate menghasilkan nilai critical ratio sebesar 1,581 yang juga masih berada di antara $-2,58$ sampai $\pm 2,58$.

Selain itu data yang digunakan dalam penelitian ini menurut pengamatan tidak terdeteksi sebagai outlier, karena nilai mahalonobis $d$-squared tidak ada yang lebih besar dari nilai critical value of chi square 0,001 dengan $\mathrm{dF}$ sebesar 5 yaitu $\mathrm{X}^{2}=20,51501$. Sehingga, data yang digunakan telah memenuhi asumsi uji outlier dan layak digunakan pada tahap selanjutnya.

\section{Uji Kelayakan Model}

Uji ini dimaksudkan untuk mengetahui seberapa besar hasil model mampu menjelaskan variasi data variable asli. Pengujian dilakukan dengan melihat koefisien determinasi total $\left(R^{2}\right.$ total) dengan formula (1) dengan batasan $R_{1}{ }^{2}, R_{2}{ }^{2}$, dan $R_{3}{ }^{2}$ masing-masing adalah $R$-square untuk masing-masing tiga variabel terikat perceived usefulness, perceived risk, dan niat pembelian.

$$
\begin{aligned}
& R^{2} \text { total }=\left\{1-\left(1-R_{1}{ }^{2}\right)\left(1-R_{2}{ }^{2}\right)\left(1-R_{3}{ }^{2}\right)\right\} \\
& =\{1-(1-0,310)(1-0,023)(1-0,442)\} \\
& =\{1-(0,69)(0,98)(0,56)\} \\
& =\{1-0,38\} \\
& =0,62 \approx 62 \% \\
& R^{2} \text { total }=0,62 \text { atau } 62 \%
\end{aligned}
$$


Ursila Imro'atu Wakhida dan Sanaji. Peran Perceived Usefulness dan Perceived Risk sebagai Variabel Pemediasi pada Pengaruh Perceived Ease of Use dan e-WOM Negatif terhadap Niat Pembelian Para Pengguna Aplikasi Layanan Kesehatan Halodoc

Hasil ini menunjukkan bahwa model memiliki kelayakan yang baik, karena kontribusi model untuk menjelaskan hubungan struktural dari kelima variabel yang di teliti dalam penelitian ini sebesar $62 \%$, sedangkan sisanya sebesar 38\% di jelaskan oleh variabel lain dan variabel error.

\section{Uji Hipotesis}

Uji hipotesis dapat dilihat dengan membandingkan nilai probabilitas $(\mathrm{P})$ dengan taraf signifikansi $(\alpha)$ yaitu sebesar 0,05. Artinya, suatu hipotesis dapat diterima apabila nilai P yang dihasilkan kurang dari atau sama dengan $\alpha$. Namun, apabila nilai $\mathrm{P}$ lebih dari $\alpha$ maka suatu hipotesis ditolak. Selanjutnya, suatu hipotesis dapat diterima atau tidak dapat dilihat dengan membandingkan nilai CR (critical ratio) hitung dengan CR standart pada $\alpha$ sebesar 0,05 yaitu 2,00. Apabila suatu hipotesis memiliki CR hitung $\geq 2,00$ maka suatu hubungan variabel signifikan dan terdapat pengaruh variabel eksogen terhadap variabel endogen.

Tabel 3.

\section{HASIL UJI HIPOTESIS}

\begin{tabular}{lccccc}
\hline & Hipotesis Jalur & C.R. & P & R-square \\
\hline Perceived usefulness & $\leftarrow$ & Perceived ease of use & 9,449 & $* * *$ & 0,310 \\
Perceived risk & $\leftarrow$ & EWOM negatif & 2,169 & 0,030 & 0,023 \\
Niat pembelian & $\leftarrow$ & Perceived ease of use & 2,998 & 0,003 & 0,442 \\
Niat pembelian & $\leftarrow$ & Perceived usefulness & 8,148 & $* * *$ & \\
Niat pembelian & $\leftarrow$ & Perceived risk & 2,348 & 0,019 & \\
\hline
\end{tabular}

Sumber: Output AMOS 22.0, data diolah

Berdasarkan tabel 3, hipotesis pertama (H1) mengenai hubungan perceived ease of use terhadap perceived usefulness terdapat nilai CR hitung sebesar 9,449 > 2,00 dan nilai signifikansi 0,000 < 0,05, maka menunjukkan bahwa hipotesis 1 (H1) diterima, artinya variabel perceived ease of use berpengaruh positif signifikan terhadap perceived usefulness. Hipotesis $2(\mathrm{H} 2)$ mengenai hubungan perceived usefulness terhadap niat pembelian terdapat nilai CR hitung sebesar 8,148>2,00 dan nilai signifikansi $0,000<0,05$, maka menunjukkan bahwa hipotesis $2(\mathrm{H} 2)$ diterima, artinya variabel perceived usefulness berpengaruh positif signifikan terhadap niat pembelian. Selanjutnya hipotesis 3 (H3) mengenai hubungan perceived ease of use terhadap niat pembelian terdapat nilai CR hitung sebesar 2,998>2,00 dan nilai signifikansi $0,003<0,05$, maka menunjukkan bahwa hipotesis 3 (H3) diterima, artinya variabel perceived ease of use berpengaruh positif signifikan terhadap niat pembelian. Pada hipotesis 4 (H4) mengenai hubungan EWOM negatif terhadap perceived risk terdapat nilai CR hitung sebesar 2,169 $>2,00$ dan nilai signifikansi $0,030<0,05$, maka menunjukkan bahwa hipotesis 4 (H4) diterima, artinya variabel EWOM negatif berpengaruh positif signifikan terhadap perceived risk. Terakhir, hipotesis 5 (H5) mengenai hubungan perceived risk terhadap niat pembelian terdapat nilai CR hitung sebesar 2,348 $>$ 2,00 dan nilai signifikansi 0,019<0,05, maka menunjukkan bahwa hipotesis 5 (H5) diterima, artinya variabel perceived risk berpengaruh positif signifikan terhadap niat pembelian.

Selanjutnya untuk uji direct, indirect, dan total effect antara variabel perceived ease of use terhadap perceived usefulness dilihat dari nilai standardized direct effects yaitu bernilai 0,557. Kemudian antara variabel EWOM negatif terhadap perceived risk dilihat dari nilai standardized direct effects yaitu bernilai 0,152 . Sedangkan untuk variabel perceived ease of use terhadap niat pembelian memiliki nilai standardized direct effects sebesar 0,191 dan pada variabel EWOM negatif terhadap niat pembelian memiliki nilai standardized direct effect sebesar 0,000. Berdasarkan hasil analisis tersebut dapat dijelaskan bahwa nilai dari standardized direct effects perceived ease of use terhadap perceived usefulness dan EWOM negatif terhadap perceived risk lebih besar dari nilai pengaruh langsung perceived ease of use dan EWOM negatif terhadap niat pembelian. Sehingga, variabel perceived usefulness dan perceived risk tidak dapat menjadi variabel yang berdiri sendiri dan menjadi variabel mediasi atau variabel perceived usefulness dan perceived risk tidak dapat menjadi variabel bebas. 
Menurut Baron \& Kenny (1986), mediasi dapat terjadi secara penuh ataupun parsial. Mediasi penuh terjadi variabel mediator ketika memenuhi empat kondisi, yaitu (1) antar variabel yang diuji berkorelasi signikan, (2) koefisien jalur variabel independen terhadap variabel mediator signifikan, (3) koefisien jalur variabel mediator terhadap variabel dependen signifikan, dan (4) ) koefisien jalur variabel mediator terhadap variabel dependen tetap signifikan, ketika variabel independen ditambahkan dalam persamaan untuk memprediksi variabel dependen. Berdasarkan konstruksi model penelitian, uji mediasi pada penelitan ini ada satu yang dapat dipastikan terbukti secara parsial (partially mediated) yaitu pada hubungan antara perceived ease of use terhadap niat pembelian dengan variabel perceived usefulness sebagai variabel mediasi. Hal ini dikarenakan pengaruh variabel perceived ease of use terhadap niat pembelian signifikan dengan nilai sebesar 0,553. Kemudian ketika ditambahkan variabel mediasi yaitu perceived usefulness, pengaruh variabel perceived ease of use terhadap niat pembelian nilainya menurun tetapi tidak sama dengan nol yaitu sebesar 0,207. Sedangkan hasil uji mediasi pada hubungan antara EWOM negatif terhadap niat pembelian dengan variabel perceived risk sebagai variabel mediasi terbukti tidak dapat dipastikan hasilnya menggunakan metode Baron dan Kenny, tetapi terbukti dapat digunakan secara parsial, karena nilai korelasi sederhana perceived ease of use dengan niat beli sebesar 0,314 yang signifikan pada alpha $0,01 \%$.

Untuk melengkapi uji mediasi, dilakukan uji pengaruh tidak langsung menggunakan metode Sobel Test (Ghozali, 2016:236). Uji ini dilakukan dengan cara menguji kekuatan pengaruh tidak langsung variabel independen $(\mathrm{X})$ ke variabel dependen $(\mathrm{Y})$ melalui variabel intervening $(\mathrm{Z})$. Jika nilai probabilitas signifikansinya sebesar $0,0001(\mathrm{P} \leq 0,05)$, maka dapat dikatakan bahwa terjadi pengaruh mediasi (Ghozali, 2016:243). Berdasarkan hasil uji sobel test menunjukkan bahwa dari kedua variabel mediasi yaitu variabel perceived usefulness dan perceived risk memiliki nilai 0,00. Karena nilai $\mathrm{p}$-value $\leq 0,05$, maka kedua variabel tersebut memiliki pengaruh tidak langsung atau dengan kata lain terbukti memediasi hubungan antara perceived ease of use dengan niat pembelian, dan EWOM negatif dengan niat pembelian.

\section{Pengaruh Perceived Ease Of Use (X1) terhadap Niat Pembelian (Y)}

Hasil penelitian ini menunjukkan bahwa perceived ease of use terhadap niat pembelian terdapat pengaruh positif, yang artinya jika perceived ease of use mengalami peningkatan, maka akan meningkatkan niat pembelian pengguna aplikasi layanan kesehatan Halodoc. Hasil penelitian ini sesuai dengan teori menurut Ahn et. al, (2014) bahwa ada efek positif dari konstruksi TAM utama (yaitu manfaat yang dirasakan dan kemudahan penggunaan) dan kepercayaan pada niat beli. Hasil penelitian ini juga mendukung penelitian terdahulu yang dilakukan oleh (Damayanti, 2019; Eriska, 2018) yang menunjukkan bahwa perceived ease of use berpengaruh positif terhadap niat pembelian. Namun hasil penelitian ini tidak mendukung penelitian dari Kucukusta et. al, (2015) yang mengemukakan bahwa perceived ease of use tidak begitu berpengaruh dalam membentuk niat penggunaan, karena dalam konteks ini responden yang menggunakan internet setiap hari dan melakukan pembelian produk layanan kesehatan online merasakan manfaat lebih penting daripada kemudahan penggunaan aplikasi layanan kesehatan Halodoc.

\section{Pengaruh Perceived Ease Of Use (X1) terhadap Perceived Usefulness (Z1)}

Pengaruh perceived ease of use berpengaruh positif signifikan terhadap perceived usefulness. Artinya apabila perceived ease of use mengalami peningkatan, maka akan meningkatkan perceived usefulness pengguna aplikasi layanan kesehatan Halodoc. Sehingga hasil ini sesuai dengan teori TAM menurut David (1989; dalam Fatmawati, 2015) bahwa perceived ease of use dan perceived usefulness adalah dua komponen yang saling memengaruhi. Teknologi informasi diawali dengan adanya persepsi mengenai manfaat (usefulness) dan persepsi mengenai kemudahan (ease of use) (Davis, 1989). Oleh karena itu, perceived ease of use mencerminkan seberapa besar perceived usefulness dari aplikasi layanan kesehatan Halodoc bagi konsumen. Hasil penelitian ini mendukung penelitian terdahulu yang dilakukan oleh (Eriska, 2018; Santoso, 2010; Kucukusta et.al, 2015; Bendary, N., \& Al-Sahouly, I, 2018) yang menunjukkan bahwa perceived ease of use berpengaruh positif terhadap perceived usefulness. Berdasarkan hasil jawaban responden pada angket yang disebarkan secara online untuk mengukur perceived ease of use item pernyataan tertinggi yaitu "Konsultasi mudah dipantau melalui 
Ursila Imro'atu Wakhida dan Sanaji. Peran Perceived Usefulness dan Perceived Risk sebagai Variabel Pemediasi pada Pengaruh Perceived Ease of Use dan e-WOM Negatif terhadap Niat Pembelian Para Pengguna Aplikasi Layanan Kesehatan Halodoc

smartphone". Hal ini dikarenakan Aplikasi Halodoc merupakan aplikasi layanan kesehatan online yang di akses melalui smartphone.

\section{Pengaruh Perceived Usefulness (Z1) terhadap Niat Pembelian (Y)}

Pada pengaruh perceived usefulness terhadap niat pembelian terdapat pengaruh positif, yang artinya jika perceived usefulness mengalami peningkatan, maka akan meningkatkan niat pembelian terhadap pengguna aplikasi layanan kesehatan Halodoc. Hasil penelitian ini sesuai dengan teori menurut Ahn et. al, (2014) bahwa ada efek positif dari konstruksi TAM utama (yaitu manfaat yang dirasakan dan kemudahan penggunaan) dan kepercayaan pada niat beli. Hasil penelitian ini juga mendukung penelitian terdaulu yang dilakukan oleh Eriska (2018) yang menunjukkan bahwa terdapat pengaruh yang signifikan antarapPerceived usefulness terhadap Niat pembelian. Namun hasil penelitian ini tidak mendukung penelitian dari Damayanti (2019) yang mengemukakan bahwa perceived usefulness tidak memiliki pengaruh positif dan signifikan terhadap niat pembelian. Variabel perceived usefulness dalam penelitian ini diukur menggunakan empat indikator yaitu mempercepat konsultasi kesehatan, mengatasi kebutuhan, meningkatkan produktivitas, efektivitas, mempermudah pekerjaan, dan bermanfaat. Berdasarkan hasil jawaban responden pada angket yang disebarkan secara online untuk mengukur perceived usefulness item pernyataan tertinggi yaitu "Menggunakan aplikasi Halodoc menghemat waktu saya". Hal ini dikarenakan dengan adanya aplikasi layanan kesehatan Halodoc, ketika sakit dan dalam keadaan darurat membutuhkan pemeriksaan dan obat segera, dapat langsung menggunakan layanan kesehatan yang tersedia pada aplikasi Halodoc tanpa pergi ke rumah sakit yang membutuhkan waktu lama.

\section{Pengaruh EWOM Negatif (X2) terhadap Perceived Risk (Z2)}

EWOM negatif terhadap perceived risk terdapat pengaruh positif. Artinya jika EWOM negatif mengalami peningkatan, maka akan meningkatkan perceived risk atau risiko yang dirasakan pengguna aplikasi layanan kesehatan Halodoc. Hasil penelitian ini sesuai dengan teori menurut Indiani et al., (2015) bahwa informasi yang diberikan melalui EWOM kemudian digunakan sebagai pertimbangan bagi konsumen sebelum melakukan pembelian produk. Hasil dalam penelitian ini juga mendukung hasil penelitian terdahulu yang dilakukan oleh Eriza, (2017) yang menyatakan bahwa EWOM berpengaruh signifikan terhadap persepsi risiko. Namun hasil penelitian ini tidak mendukung penelitian dari Indiani et al., (2015) yang menyatakan bahwa aktivitas EWOM memiliki pengaruh negatif terhadap persepsi risiko konsumen yang akan melakukan pembelian secara online. Karena dalam konstruk ini dijelaskan bahwa semakin meningkatnya EWOM negatif, maka akan meningkatkan perceived risk pengguna aplikasi layanan kesehatan Halodoc. Dalam penelitian ini variabel EWOM negatif diukur menggunakan tiga indikator yaitu frekuensi mengakses informasi dari media sosial, informasi mengenai keamanan transaksi dan situs jejaring internet yang disediakan, serta rekomendasi dari pengguna media sosial. Berdasarkan hasil jawaban responden pada angket yang disebarkan secara online untuk mengukur EWOM negatif item pernyataan tertinggi yaitu "Sering mencari keterangan lewat review online aplikasi Halodoc untuk membantu memilih jasa yang benar". Hal ini dikarenakan semakin tinggi tingkat frekuensi pencarian informasi melalui review online pada aplikasi Halodoc dapat menambah pengetahuan tentang jasa layanan kesehatan yang sesuai dengan keinginan konsumen.

\section{Pengaruh Perceived Risk (Z2) terhadap Niat Pembelian (Y)}

Pengaruh perceived risk terhadap niat pembelian terdapat pengaruh positif, yang artinya jika perceived risk, maka akan meningkatkan niat pembelian pengguna aplikasi layanan kesehatan Halodoc. Hasil penelitian ini sesuai dengan teori menurut Mulyana (2016) bahwa perceived risk menekankan pada anggapan tentang adanya risiko yang akan diterima seseorang saat melakukan transaksi online. Semakin tinggi perceived risk menyebabkan seseorang mempunyai ketakutan lebih tinggi saat bertransaksi secara online. Sebaliknya perceived risk yang rendah membuat seseorang tidak merasa takut dalam melakukan transaksi online. Hasil penelitian ini juga mendukung penelitian terdahulu dari (Haekal dan Widjajanta, 2016; Eriza, 2017) yang menunjukkan bahwa perceived ease of use berpengaruh positif terhadap niat pembelian. Namun hasil penelitian ini tidak mendukung penelitian dari Indiani et. al, (2015) yang menunjukkan bahwa perceived risk memiliki pengaruh negatif terhadap niat pembelian. Karena dalam konstruk ini dijelaskan bahwa semakin meningkatnya perceived risk, maka akan 
meningkatkan niat pembelian pengguna aplikasi layanan kesehatan Halodoc. Dalam penelitian ini variabel Perceived risk diukur menggunakan lima dimensi yaitu risiko kinerja, risiko keuangan/transaksi, risiko waktu, risiko pengiriman, dan risiko psikologis. Berdasarkan hasil jawaban responden pada angket yang disebarkan secara online untuk mengukur perceived risk item pernyataan tertinggi yaitu "Saya khawatir pemberian informasi yang kurang jelas dari dokter menimbulkan kesalahan penafsiran". Hal ini dikarenakan proses pemeriksaan kesehatan yang dilakukan pada aplikasi Halodoc dilakukan melalui video call, telepon, atau chat dan tidak bertatap muka secara langsung, sehingga konsumen merasa khawatir dengan adanya risiko akan kesalahan penafsiran pada informasi yang disampaikan oleh dokter.

Variabel niat pembelian diukur dengan empat indikator yaitu tertarik untuk mencari informasi mengenai produk, mempertimbangkan untuk membeli, tertarik untuk mencoba, dan keinginan untuk melakukan pembelian dalam waktu dekat. Berdasarkan hasil jawaban responden pada angket yang disebarkan secara online untuk mengukur niat pembelian item pernyataan tertinggi yaitu "Saya tertarik mencoba jenis layanan jasa kesehatan di aplikasi Halodoc". Hal ini dikarenakan jasa yang ditawarkan oleh aplikasi Halodoc sangat beragam dan lengkap. Hampir semua layanan yang biasanya hanya bisa dilakukan dengan pergi ke rumah sakit, disediakan oleh aplikasi Halodoc. Beberapa layanan yang ada dalam aplikasi Halodoc adalah bicara dengan dokter (Tanya Dokter), beli obat, pemeriksaan laboratorium, kunjungi rumah sakit (daftar nomer antrian), perlindungan kesehatan, layanan antar obat (Halodoc Go), dan hospital directory.

Terdapat implikasi teoritis yang dihasilkan dari penelitian ini. Penelitian ini mendukung kerangka teoritis niat pembelian bahwa variabel perceived ease of use, perceived usefulness, dan perceived risk berpengaruh positif terhadap niat pembelian. Selanjutnya efek mediasi oleh perceived usefulness juga mendukung beberapa penelitian sebelumnya yang memediasi secara signifikan antara variabel perceived ease of use terhadap niat pembelian. Efek mediasi oleh perceived risk tidak mendukung beberapa penelitian sebelumnya, karena tidak memediasi antara variabel EWOM negatif terhadap niat pembelian. Selain itu implikasi dari penelitian ini terhadap perusahaan atau pemasar yang dalam hal ini merupakan pembuat aplikasi adalah pertama, berdasarkan karakteristik responden, banyak didominasi oleh perempuan daripada laki-laki. Usia didominasi antara 21-25 tahun dengan pekerjaan sebagai pelajar/mahasiswa. Hal ini bermanfaat bagi pembuat aplikasi untuk lebih fokus dalam mepromosikan aplikasi terhadap konsumen dan calon konsumen dengan karakteristik tersebut. Kemudian, selain karakteristik responden, pembuat aplikasi juga disarankan untuk memberikan kualitas aplikasi yang terbaik berdasarkan beberapa dimensi yang sesuai serta membuat aplikasi lebih bermanfaat sehingga menjadikan pengguna aplikasi merasakan kemudahan ketika menggunakan aplikasi tersebut dan kebermanfaatan yang diterima dari aplikasi tersebut sehingga konsumen dan calon kosumen merasa tertarik untuk menggunakan dan membeli jasa layanan kesehatan yang ada dalam fitur aplikasi serta diharapkan berimbas terhadap niat pembelian.

Penelitian ini tidak terlepas dari beberapa keterbatasan atau hambatan. Pengambilan data responden yang secara online melalui instagram dan whatsapp, tidak bisa menjadi patokan untuk dapat menyebar angket secara online dengan merata sesuai dengan usia pada kriteria 21 - > 50 tahun. Hasil dari nilai multikolinearitas dilihat dari nilai determinan of sampel covariance matrix yaitu 0,001 menjadi kekurangan dari penelitian ini, karena nilai yang diperoleh seharusnya menjauhi 0. Kemudian pada variabel perceived risk yang terbukti tidak memediasi antara variabel EWOM negatif terhadap niat pembelian. Karena keterbatasan jurnal atau artikel yang membahas tentang variabel perceived risk sebagai variabel yang memediasi antara EWOM negatif terhadap niat pembelian.

\section{KESIMPULAN}

Berdasarkan hasil penelitian dan analisis data beserta hasil penelitian ini, maka kesimpulan dari penelitian ini adalah perceived ease of use berpengaruh positif terhadap niat pembelian, perceived ease of use berpengaruh positif terhadap perceived usefulness, perceived usefulness berpengaruh positif terhadap niat pembelian, EWOM negatif berpengaruh positif terhadap perceived risk, perceived risk 
Ursila Imro'atu Wakhida dan Sanaji. Peran Perceived Usefulness dan Perceived Risk sebagai Variabel Pemediasi pada Pengaruh Perceived Ease of Use dan e-WOM Negatif terhadap Niat Pembelian Para Pengguna Aplikasi Layanan Kesehatan Halodoc

berpengaruh positif terhadap niat pembelian, serta perceived usefulness terbukti memediasi secara parsial, dan perceived risk terbukti tidak memediasi.

Saran untuk penelitian selanjutnya alangkah lebih baik jika pengambilan data responden dilakukan secara langsung, sehingga data yang diperoleh lebih beragam dan diharapkan dapat memberikan hasil penelitian yang lebih baik. Kemudian untuk pembuat aplikasi diharapkan mampu memerhatikan kemudahan dalam penggunaan aplikasi dan manfaat yang dapat dirasakan oleh konsumen ketika menggunakan aplikasi tersebut sehingga terbentuklah EWOM positif untuk mengurangi adanya risiko yang ada pada aplikasi dan berdampak pada niat pembelian terhadap layanan kesehatan pada aplikasi tersebut. Alangkah lebih sempurna, jika menambahkan variabel trust dalam penelitian selanjutnya, karena dalam teori TRITAM tidak hanya menambahkan variabel risk namun juga menambahan variabel trust.

Berdasarkan fenomena yang terjadi akibat wabah Covid-19, sepanjang tahun 2020 diprediksi akan menjadikan teknologi informasi di Indonesia bahkan seluruh dunia terutama aplikasi layanan kesehatan menjadi media utama dalam melakukan konsultasi dengan dokter, karena risiko yang besar ketika berkunjung langsung ke rumah sakit akan tertular wabah tersebut. Hal ini menjadikan industri start up layanan kesehatan di Indonesia akan meningkat drastis, sehingga akan muncul pesaing-pesaing baru dalam industri layanan kesehatan online. Antisipasi yang dapat dilakukan adalah dengan inovasi fiturfitur layanan yang lebih banyak dibutuhkan oleh konsumen sebagai pelengkap aplikasi sebelumnya. Dengan demikian akan menjadikan keuntungan jika dapat menarik konsumen dan calon konsumen dalam jumlah besar.

\section{DAFTAR PUSTAKA}

Ahn, T., Suh, Y.I., Lee, J.K., \& Pedersen, P.M. (2014). Understanding Purchasing Intention in Secondary Sports Ticket Website. International Journal of Sports Marketing \& Sponsorship, $16(1), 35-49$.

Bambauer-Saches, S., \& Mangold, S. (2011). Brand Equity Dilution Trough Negative Online WordOf-Mouth Communication. Journal of Retailing and Consumer Services, 18, 38-45.

Baron, R.N., \& Kenny, D.A. (1986). The Moderator-Mediator Variable Distinction in Social Psychological Research: Conceptual, Strategic, and Statistical Considerations, 51(6), 1173-1182.

Damayanti, V. (2019). Pengaruh Perceived Usefulness dan Perceived Ease of Use Terhadap Purchase Intention Melalui Brand Image Sebagai Variabel Intervening Pada Mahasiswa UST Yogyakarta Pengguna Shopee. Ilmiah Ekonomi dan Bisnis, 16, 99-109.

Davis, F.D. (1989). Perceived usefulness, Perceived ease of use, and user Acceptance of information technology. MIS Quarterly, 13(13), 319-340.

Eriza, Z.N. (2017). Peran Mediasi Citra Merek dan Persepsi Risiko Pada Hubungan Antara Electronic Word Of Mouth (E-WOM) dan Minat Beli (Studi Pada Konsumen Kosmetik E-Commerce di Solo Raya. Komuniti, 9(1), 14-24.

Erkan, I., \& Evans, C. (2016). The Influence of eWOM in social media on cosumers purchase intentions: An extended approach to information adoption, 61, 47-55.

Fatmawati, Endang. (2015). Technology Acceptance Model (Tam) Untuk Menganalisis Penerimaan Terhadap Sistem Informasi Perpustakaan. Jurnal Iqra', 9(1). 
Ferdinand, Augusty. (2006). Metode penelitian Manajemen: "Pedoman Penelitian Untuk Penulisan Skripsi, Tensis, dan disertai Ilmu Manajemen". Semarang: Badan Penerbit Universitas Diponogoro.

Ghozali, I. (2016). Aplikasi Analisis Multivariate dengan Program IBM SPSS 23 (Edisi 8). Cetakan ke VIII. Semarang: Badan Penerbit Universitas Diponegoro.

Goyette et.al. (2010). E-WOM Scale: Word-of-Mouth Measurement Scale for e-Services Context. Canadian Journal of Administrative Sciences, 27, 5-23.

Haekal, A., \& Widjajanta, B. (2016). Pengaruh Kepercayaan Dan Persepsi Risiko Terhadap Minat Membeli Secara Online Pada Pengunjung Website Classifieds Di Indonesia. Journal of Business Management and Enterpreneurship Education, 1, 181-193.

Idtesis.com. (2018). Teori Lengkap tentang Technology Acceptance Model (TAM) menurut Para Ahli dan Contoh Tesis Technology Acceptance Model (TAM). (https://idtesis.com/teori-lengkaptentang-technology-acceptance-model-tam-menurut-para-ahli-dan-contoh-tesis-technologyacceptance-model-tam/, diakses pada 29 Oktober 2019).

Indiani et.al. (2015). Perceived Risk and Trust as Major Determinants of Actual Purchase, Transcending The Influence of Intention. ASEAN Marketing Journal, 7(1), 1-13.

Karami, K.A., \& Wismiarsi, T. (2016). Pengaruh Risiko Pada Keputusan Belanja Online. Prosiding Seminar Nasional INDOCOMPAC, 320-333.

Kim et.al. (2008). An Empirical Study On The Integrated Framework of e-CRM in Online Shoping: Evaluating the Relationships Among Perceived value, Satisfaction and Trust Based on Customer Perspective. Journal of Elecreonis Commerce in Organization, 6(3), 1-19.

Kucukusta et.al. (2015). Re-examining Perceived Usefulness and Ease of Use in Online Booking: The Case of Hong Kong online users. International Journal of Contemporary Hospitality Management, 27, 185-198.

Lea, Eriska. (2018). Pengaruh Perceived Ease of Use dan Faktor Lain Terhadap Niat Kaum Milenial dalam Menggunakan Transportasi Berbasis Aplikasi, 1-18.

Maulana, Rizqi. (2017). Kumpulan Start up Kesehatan Terbaik di Indonesia. (https://id.techinasia.com/kumpulan-start up-kesehatan-di-indonesia, diakses pada 30 Oktober 2019).

Mildawati, Titik. (2016). Teknologi Informasi dan Perkembangannya. Ekuitas, 4(2), 101-110.

Mulyana, Y.F. (2016). Pengaruh Kepercayaan, Persepsi Risiko, dan Keamanan Terhadap Minat Beli Konsumen Pada Toko Online (Studi Pada Toko Online Olx.Co.Id).

Nuseir, M.T. (2019). The Impact of Electronic Word of Mouth (eWOM) on The Online Purchase Intention of Consumers in the Islamic Countries - a Case of (UAE). Islamic Marketing, 1-9.

Retnowati, N. (2017). Pengaruh E-WOM (Electronic Word of Mouth) Pada Situs Social Commerce Terhadap Niat Beli Generasi X,Y, dan Z.

Rosian, A., \& Wijaya, A. (2016). Pengaruh Kepercayaan dan Risiko Pada Minat Beli Belanja Online. Jurnal Manajemen dan Bisnis Sriwijaya, 14, 155-168. 
Ursila Imro'atu Wakhida dan Sanaji. Peran Perceived Usefulness dan Perceived Risk sebagai Variabel Pemediasi pada Pengaruh Perceived Ease of Use dan e-WOM Negatif terhadap Niat Pembelian Para Pengguna Aplikasi Layanan Kesehatan Halodoc

Sanaji, Sanaji. (2018). Eksplorasi Dampak Komunitas Merek Online Di Media Sosial Terhadap Konsistensi Hubungan Konsumen Dengan Merek. Journal of Research in Economics and Management, 15(2), 382-395.

Santoso, B. (2010). Pengaruh Perceived Usefulness, Perceived Ease of Use, dan Perceived Enjoyment Terhadap Penerimaan Teknologi Informasi (Studi Empiris di Kabupaten Sragen).

Schiffman, dan Kanuk. (2010). Consumer Behavior Tenth Edition. Pearson Education.

See-To, E.W.K., \& Ho, K.K.W. (2014). Value Creation and Purchase Intention in Social Network Sites: The Role of Electronic Word-of-Mouth and Trust - A Theoretical Analysis. Computers in Human Behavior, 31, 182-189.

Sugiyono. (2016). Metode Penelitian Kuantitatif Kualitatif dan Kombinasi (Mixed Methods). Bandung: ALFABETA.

Suhir, M., Suyadi, I., \& Riyadi. (2014). Pengaruh Persepsi Risiko, Kemudahan dan Manfaat Terhadap Keputusan Pembelian Secara Online (Survei Terhadap Pengguna Situs Website www.Kaskus.co,id). Jurnal Administrasi Bisnis, 8(1), 1-10.

Tien, R., \& Liao. (2018). Examining The Influence of Customer-to customer Electronic Word of Mouth on Purchase Intention in Social Networking Sites, 1-12. 